\title{
Energy expenditure of soldiers in a warm humid climate
}

\author{
By M. F. HAISMAN* \\ Army Personnel Research Establishment, West Byfleet, Surrey
}

(Received 6 May 1971-Accepted 6 October 1971)

\begin{abstract}
I. Energy expenditure determinations have been made on thirty-two soldiers newly arrived in the warm humid climate of southern Malaya. Ergometer cycling was investigated as well as everyday activities such as lying, sitting, riding in a truck, ablutions, building a jungle camp and walking with loads over four different routes.

2. The inter-individual variation in the gross energy expenditure ( $\mathrm{kcal} / \mathrm{min}$ and $\mathrm{kJ} / \mathrm{min}$ ) of each activity has been compared with the variation in energy expenditure standardized for body-weight, surface area and lean body mass. Standardization for body size did not consistently or effectively reduce the coefficients of variation of energy expenditure.

3. The gross energy expenditure of most activities was significantly correlated with bodyweight, surface area or lean body mass but the correlation coefficients were not of a high order, suggesting that less than $4 \mathrm{I} \%$ of the inter-individual variation in energy expenditure was accounted for by variation in body size.

4. The energy expenditure of walking at various speeds over both firm and uneven terrain was related to the square of the walking speed and the total weight of the man and his equipment (correlation coefficients $0.89-0.92, P<0.001$ ).
\end{abstract}

The energy expended by man for such activities as lying, sitting and walking has been observed to show considerable inter-individual variation (Booyens \& Keatinge, I957; Booyens \& McCance, I957; Edholm, Fletcher, Widdowson \& McCance, 1955). Body-weight, body surface area and lean body mass have all been used as standards of reference in attempts to account for the variations in energy metabolism, and the subject has been reviewed (Kleiber, 1947; Durnin, 1965; von Döbeln, 1956; Tanner, 1949).

A study was made and the results were analysed to ascertain whether body-weight, surface area or lean body mass can account for the variations between men in the energy expenditure of normal daily activities.

\section{EXPERIMENTAL}

\section{Subjects}

The study was carried out in southern Malaya. The mean physical characteristics of the thirty-two soldier subjects are given in Table $\mathrm{r}$. The subjects were not acclimatized to the warm climate of Malaya since the investigations commenced in January 1970 , I d after their arrival from the relatively cool climate of Hong Kong.

\section{Methods}

Energy expenditure was measured by the method of indirect calorimetry. KofranyiMichaelis respirometers (Kofranyi \& Michaelis, 1940) were used for all determinations with the exception of those on eight men in the cycling studies, who were

* Present address : Military Ergonomics Laboratory, US Army Research Institute of Environmental Medicine, Natick, Mass. o 760 , USA. 
tested by the Douglas Bag technique. The respirometers were calibrated every day by the method of Durnin \& Brockway (1959). For measurements of short duration (e.g. cycling) the respirometers were used with mouthpieces, but for longer activities (e.g. walking) respiratory valves were fitted into oronasal masks. Samples of expired air were collected into polyvinylchloride bags which have been found to be relatively impermeable to respiratory gases. Sample bags of 51 capacity were used to allow collection for about $\mathrm{I} h$. Expired air samples were analysed for oxygen and carbon dioxide, respectively, by means of a Beckman $\mathrm{E} 2$ Analyzer and a gas chromatograph (Pye). The analysers were calibrated with high-pressure gas mixtures, the composition of which had been checked with the Lloyd-Haldane apparatus.

Skinfold thickness measurements were made with Harpenden skinfold calipers. Body fat content was calculated from the sum of the thicknesses at four sites by the method of Durnin \& Rahaman (1967). Lean body mass was derived by subtraction of the fat weight from body-weight.

Table I. Physical characteristics of the thirty-two subjects

$\begin{array}{lcccc}\text { Age } & \begin{array}{c}\text { Height } \\ (\mathrm{cm})\end{array} & \begin{array}{c}\text { Weight } \\ \text { (kg) }\end{array} & \begin{array}{c}\text { Lean body } \\ \text { mass* } \\ (\mathrm{kg})\end{array} \\ \text { Mean } & 21 \cdot 3 & 173.5 & 70 \cdot 26 & 59.8 \mathbf{1} \\ \text { SD } & 2 \cdot 4 & 5.2 & 8.58 & 5.69\end{array}$

* Estimated from four skinfold thickness measurements and body-weight.

$\begin{array}{lc}\text { Activity } & \begin{array}{c}\text { Duration } \\ \text { of } \\ \text { measure- } \\ \text { ment } \\ \text { (min) }\end{array} \\ \begin{array}{l}\text { Lying } \\ \text { Sitting }\end{array} & 30 \\ \text { Riding in a truck } & 20 \\ \text { Ablutions } & 44 \\ \text { Jungle camp } & 25 \\ \text { building } & 37 \\ \text { Cycling } & 2-5 \\ & \\ \begin{array}{l}\text { Walking (various } \\ \text { speeds over } \\ \text { different } \\ \text { terrains) }\end{array} & 50-52 \\ & 67-72 \\ & 29-50 \\ & 34-56\end{array}$

Table 2. Activities investigated

Descriptive notes

Lying on a blanket on the floor

Seated on a stool and simulated preparation of a meal

Seated in the back of a 3-ton truck. Journey included tracks and roads. Two mounting and dismounting sequences carried out

Bed-making, boot cleaning, water carrying, undressing, washing, shaving and dressing

Walking with equipment, collecting wood, cutting stakes and cleaning rifles

Douglas Bags used for short tests, Kofranyi-Michaelis respirometers for longer ones. Work performed at 100 and $x 50 \mathrm{~W}$ on one of three ergometers (Lanooy, Muller and Monark) at $60 \mathrm{rev} / \mathrm{min}$

Route $\mathrm{r}: 5.4 \mathrm{~km}$; firm track; finish $50 \mathrm{~m}$ above start

Route 2: $6.2 \mathrm{~km}$; firm track and road; finish $60 \mathrm{~m}$ below $24 \mathrm{~kg}$ load start

Route $3: 3 \cdot 6 \mathrm{~km} ; \mathrm{r} \cdot 2 \mathrm{~km}$ on track and the remainder over

difficult terrain (overgrown oil palm)
Route $4: 4.8 \mathrm{~km} ; 0.8 \mathrm{~km}$ over difficult terrain and the remainder on track 


\section{Activities}

The activities investigated are described in Table 2. One determination of energy expenditure was made for each subject for each activity, except for walking on routes 3 and 4 , where extra determinations were made. It was not possible to standardize the conditions for each subject in respect of such factors as previous activity, time elapsed from the last meal, time of day or environmental temperature. Lying, sitting and cycling were performed in a standardized manner, but the remaining activities were more complex. Ablutions and jungle camp building were carried out according to a programme but the component activities such as bed-making, boot cleaning and wood cutting were performed in the subjects' own way. Measurements of energy expenditure usually commenced as the activity started, but after a preliminary period of at least 2 min with the respiratory apparatus connected to the subject. However, for cycling, collection of expired air began after I min of cycling at each work load (100 W and $150 \mathrm{~W}$ ). Although three types of bicycle ergometer were used, an analysis of variance showed that there was no significant difference between the results from each ergometer. Walking over routes I and 2 was at approximately 6.3 and $5.4 \mathrm{~km} / \mathrm{h}$ respectively. In contrast, the walking speed over routes 3 and 4 was deliberately varied from day to day, ranging from a medium pace of $4.3 \mathrm{~km} / \mathrm{h}$ to the maximum speed possible for the group of $8 \cdot 5 \mathrm{~km} / \mathrm{h}$.

\section{Environmental temperature}

Temperature was recorded outdoors at intervals of $\mathrm{r} h$ with thermistor equipment. The means and ranges of the average temperature readings for each activity session were: wet-bulb temperature (exposed) $25^{\circ} 0^{\circ}\left(23^{\circ} \cdot 6-26 \cdot 2\right)$, dry-bulb temperature (shaded) $29^{\circ} 2^{\circ}\left(25^{\circ} 3-32 \cdot 0\right)$, black-globe temperature $37^{\circ} 0^{\circ}\left(25^{\circ} 8-45^{\circ} 3\right)$. However, with the exception of walking and jungle camp building, the activities were performed in the shade. The cycle tests were done in the cooler part of the day - that is, in the morning and evening - in a well-ventilated building and the means of the temperatures recorded by an Assman psychrometer were $23.6^{\circ}$ and $25^{\circ} 8^{\circ}$ for the wet- and drybulb temperatures respectively.

\section{RESULTS}

The energy-expenditure results (Table 3 ) are presented as mean values for each activity, except walking on routes 3 and 4 . The small differences between the total number of men (32) and the numbers given in Table 3 are because of absence due to minor sickness or because of technical faults. Coefficients of variation for gross energy expenditure ( $\mathrm{kcal} / \mathrm{min}$ ) have been compared with the coefficients for energy expenditure standardized for body-weight $(\mathrm{kcal} \times 65 / \mathrm{kg} \mathrm{min})$, surface area $\left(\mathrm{kcal} / \mathrm{m}^{2} \mathrm{~min}\right)$ and lean body mass ( $\mathrm{kcal} / \mathrm{kg} \mathrm{min}$.) Compared to the gross energy-expenditure coefficients, the body-size standardization did not substantially reduce the coefficient of variation and, in fact, this procedure had the opposite effect in four out of nine activities.

The energy expenditure results for walking on routes $\mathrm{I}-4$ have been treated in two ways. Firstly, energy expenditure corrected for the total weight of the man and his equipment was compared with the square of walking speed, and linear regression 
equations were calculated (Fig. I and Table 4 ). The square of walking speed was used to allow a linear analysis (Ralston, 1958). Secondly, energy expenditure ( $\mathrm{kcal} / \mathrm{min}$ ) of walking was related to total weight and walking speed (squared) in multiple regression calculations (Table 4 ). For comparison with the present results, results have also been

Table 3. Mean values together with coefficients of variation (CV) for the gross energy expenditure of the soldiers compared with energy expenditure standardized for body-weight, surface area and lean body mass, together with correlation coefficients (r) relating energy expenditure to body-weight, surface area and lean body mass

\begin{tabular}{|c|c|c|c|c|c|c|}
\hline \multirow{3}{*}{ Activity } & & & & \multicolumn{3}{|c|}{ Energy expenditure related to: } \\
\hline & & \multicolumn{2}{|c|}{$\begin{array}{c}\text { Energy } \\
\text { expenditure }\end{array}$} & \multirow{2}{*}{$\begin{array}{l}\text { Body- } \\
\text { weight } \\
(\mathrm{kcal} \times 65 / \\
\mathrm{kg} \text { min })\end{array}$} & \multirow{2}{*}{$\begin{array}{l}\text { Surface } \\
\text { area } \\
(\mathrm{kcal} / \\
\left.\mathrm{m}^{2} \mathrm{~min}\right)\end{array}$} & \multirow{2}{*}{$\begin{array}{c}\text { Lean } \\
\text { body mass } \\
\text { (kcal/ } \\
\text { kg min) }\end{array}$} \\
\hline & & $\mathrm{kcal} / \mathrm{min}$ & $\mathrm{kJ} / \mathrm{min}$ & & & \\
\hline Lying, $n=30$ & $\begin{array}{l}\text { Mean } \\
\mathrm{CV} \\
r\end{array}$ & $\begin{array}{l}1 \cdot 32 \\
17 \cdot \mathbf{I} \\
-\end{array}$ & $5 \cdot 52$ & $\begin{array}{l}1.23 \\
20.7 \\
0.12\end{array}$ & $\begin{array}{l}0.72 \\
18.2 \\
0.09\end{array}$ & $\begin{array}{l}0.022 \\
19.4 \\
0.10\end{array}$ \\
\hline Sitting, $n=3 \circ$ & $\begin{array}{l}\text { Mean } \\
\mathrm{cv} \\
r\end{array}$ & $\begin{array}{l}1 \cdot 76 \\
17 \cdot 2 \\
-\end{array}$ & $7 \cdot 36$ & $\begin{array}{l}I \cdot 65 \\
I 8 \cdot 2 \\
0.26\end{array}$ & $\begin{array}{l}0.96 \\
\mathbf{1 6 . 0} \\
0.37 *\end{array}$ & $\begin{array}{l}0.030 \\
15.9 \\
0.44^{*}\end{array}$ \\
\hline $\begin{array}{l}\text { Riding in a truck, } \\
n=3 \mathbf{I}\end{array}$ & $\begin{array}{l}\text { Mean } \\
\mathrm{CV} \\
r\end{array}$ & $\begin{array}{l}1 \cdot 99 \\
15.8 \\
-\end{array}$ & $8 \cdot 33$ & $\begin{array}{l}1.84 \\
15.9 \\
0.39 *\end{array}$ & $\begin{array}{l}1 \cdot 08 \\
15 \cdot 2 \\
0.31\end{array}$ & $\begin{array}{l}0.033 \\
15.6 \\
0.31\end{array}$ \\
\hline Ablutions, $n=29$ & $\begin{array}{l}\text { Mean } \\
\mathrm{Cv} \\
r\end{array}$ & $\begin{array}{c}3 \cdot 25 \\
16 \cdot 4 \\
-\end{array}$ & $13 \cdot 60$ & $\begin{array}{l}3.01 \\
15^{\circ} \mathrm{O} \\
0^{-} 54^{* * *}\end{array}$ & $\begin{array}{l}I \cdot 77 \\
\mathrm{x} 4 \cdot 6 \\
0.55 * *\end{array}$ & $\begin{array}{l}0.054 \\
14.0 \\
0.57 * *\end{array}$ \\
\hline $\begin{array}{l}\text { Jungle camp building, } \\
n=3 \mathrm{I}\end{array}$ & $\begin{array}{l}\text { Mean } \\
\mathrm{CV} \\
r\end{array}$ & $\begin{array}{r}3.64 \\
12.7 \\
-\end{array}$ & I $5^{\circ} \cdot 23$ & $\begin{array}{l}3.40 \\
\text { I I.6 } \\
0.58 * * *\end{array}$ & $\begin{array}{l}I \cdot 99 \\
\text { I0.5 } \\
0.60 * * *\end{array}$ & $\begin{array}{l}0.061 \\
9.9 \\
0.64 * * *\end{array}$ \\
\hline $\begin{array}{l}\text { Cycling, } 100 \mathrm{~W} \\
n=3^{\circ}\end{array}$ & $\begin{array}{l}\text { Mean } \\
\mathrm{CV} \\
r\end{array}$ & $\begin{array}{l}7 \cdot 52 \\
7 \cdot 3 \\
-\end{array}$ & $31 \cdot 46$ & $\begin{array}{l}7 \cdot 02 \\
13 \cdot 2 \\
0.13\end{array}$ & $\begin{array}{c}4.11 \\
10.0 \\
-0.02\end{array}$ & $\begin{array}{l}0.126 \\
\text { I } 13 \\
0.04\end{array}$ \\
\hline $\begin{array}{l}\text { Cycling, } 15 \circ \mathrm{W} \\
n=30\end{array}$ & $\begin{array}{l}\text { Mean } \\
\mathrm{CV} \\
r\end{array}$ & $\begin{array}{c}10 \cdot 50 \\
8 \cdot 0 \\
-\end{array}$ & $43 \cdot 93$ & $\begin{array}{l}9.83 \\
15.2 \\
-0.12\end{array}$ & $\begin{array}{c}5.74 \\
\text { II.7 } \\
-0.24\end{array}$ & $\begin{array}{c}0.177 \\
\mathrm{I}_{3.1} \\
-0.14\end{array}$ \\
\hline $\begin{array}{l}\text { Walking, } \uparrow \text { route } \mathrm{I} \text {, } \\
n=30\end{array}$ & $\begin{array}{l}\text { Mean } \\
\mathrm{CV} \\
\gamma\end{array}$ & $\begin{array}{c}9 \cdot 14 \\
10 \cdot 8 \\
-\end{array}$ & $3^{8 \cdot 24}$ & $\begin{array}{l}8-63 \\
\text { II.6 } \\
0.5 I^{* *}\end{array}$ & $\begin{array}{c}5.02 \\
10.9 \\
0.29\end{array}$ & $\begin{array}{l}0.156 \\
10.8 \\
0.36 *\end{array}$ \\
\hline $\begin{array}{l}\text { Walking, } \uparrow \text { route } 2 \\
n=28\end{array}$ & $\begin{array}{l}\text { Mean } \\
\mathrm{CV} \\
r\end{array}$ & $\begin{array}{l}6 \cdot 29 \\
9 \cdot 1 \\
-\end{array}$ & $26 \cdot 32$ & $\begin{array}{c}5 \cdot 85 \\
\text { I I.6 } \\
0.35\end{array}$ & $\begin{array}{l}3 \cdot 43 \\
9 \cdot 4 \\
0 \cdot 32\end{array}$ & $\begin{array}{c}0.105 \\
10.6 \\
0.27\end{array}$ \\
\hline
\end{tabular}

Significance of $r$ of energy expenditure (kcal/min) with body-weight, surface area and lean body mass: * $P<0.05$; ** $P<0.01$; *** $P<0.001$.

$\dagger$ Values have not been corrected for the small variations of speed indicated in Table 2.

given from a previous study (Haisman, I969) on another group of twenty-seven men, who walked with loads at four different speeds around an indoor circuit in temperate climates (dry-bulb temperature approximately $20^{\circ}$ ). The results for routes $I$ and 2 were pooled because the range of walking speeds for each was very restricted. 
Table 4. Regression equations relating energy expenditure of soldiers in walking, to total weight and walking speed

Walking route and no. of observations $I$ and 2 combined $(n=58)$

$3(n=46)$

$4(n=56)$

Previous investigation on indoor circuit (Haisman, г969) $(n= \pm 56)$

$\begin{array}{cc}\begin{array}{c}\text { Percentage } \\ \text { variation in } \\ E \text { or } E_{W}\end{array} & \begin{array}{c}\text { Standard } \\ \text { error } \\ \text { of estimate }\end{array} \\ \begin{array}{c}\text { accounted } \\ \text { for by fitting } \\ \text { equation }\end{array} & \begin{array}{c}\% \text { of mean } \\ \left.E \text { or } E_{W}\right)\end{array} \\ 76 & 10.9 \\ 80 & 9.7 \\ 85 & 10.2 \\ 84 & 10.5 \\ 79 & 12.1 \\ 80 & 12.7 \\ 88 & 12.0 \\ 86 & 13.5\end{array}$

$E$, energy expenditure (kcal/min); wt, total weight $(\mathrm{kg})$ of $\operatorname{man}+$ equipment; $V$, speed $(\mathrm{m} / \mathrm{min})$; $E_{W}$, energy expenditure (kcal $\times 100 / \mathrm{kg}$ total wt $\left.\mathrm{min}\right)$.

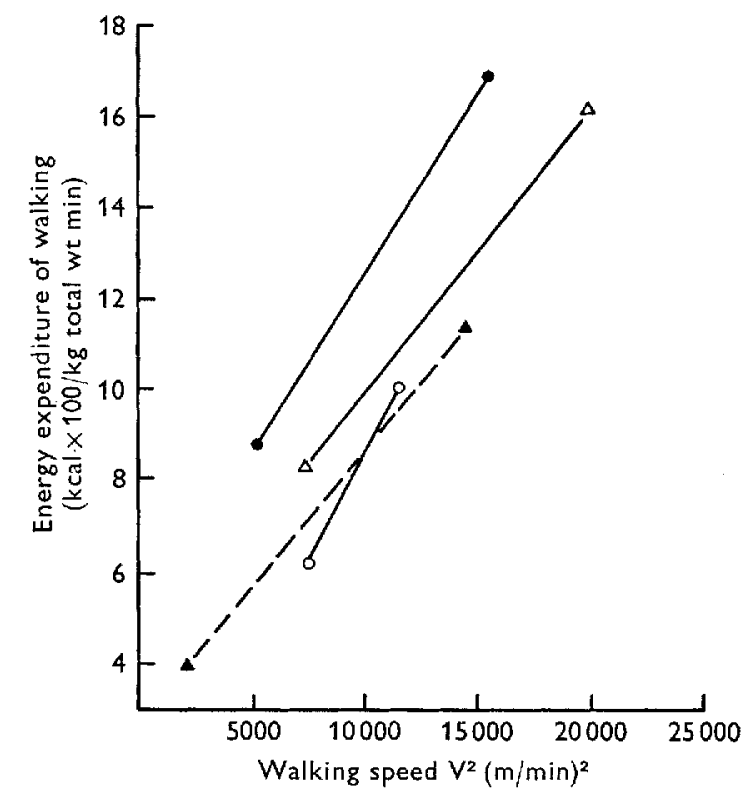

Fig. T. Linear regressions calculated for energy expenditure of soldiers (standardized for total weight) and walking speed (squared). Equations are given in Table 4. O, routes I and 2, firm track;, route $3,67 \%$ of total distance over difficult terrain; $\triangle$, route $4,17 \%$ of total distance over difficult terrain; $\Delta$, previous investigation using an indoor circuit (Haisman, I969).

\section{DISCUSSION}

The inter-individual variation observed in the energy expended on the activities in the present study (Table 3 ) appears to be of an order similar to that found by other investigators, e.g. lying and sitting (Booyens \& McCance, 1957), walking (Grimby \& 
Söderholm, 1962), cycling (Wyndham, Morrison, Williams, Strydom, von Rahden, Holdsworth, van Graan, van Rensburg, Joffe \& Heyns, xg66). However, somewhat smaller coefficients of variation were noted: $13 \%$ for lying and $12 \%$ for sitting (Edholm et al. 1955) and 3-5\% for cycling (Williams, Wyndham, Morrison \& Heyns, 1966). A higher coefficient of variation for marching, $21 \%$, was reported by Edholm, Adam, Healy, Wolff, Goldsmith \& Best (1970) compared with that found in the present study.

The degree of inter-individual variation was not altered substantially by standardizing cnergy expenditure for body size (Table 3), since the greatest reduction in the coefficients of variation was less than $3 \%$. It is probably more important to note that for activities such as cycling there was an increase in the variation after standardizing for body size. Correlation coefficients between energy expenditure $(\mathrm{kcal} / \mathrm{min})$ and body-weight, surface area and lean body mass that were statistically significant are indicated in Table 3 . These coefficients were not of a high order $(r<0.64)$, suggesting that less than $4 \mathrm{r} \%$ of the inter-individual variation in energy expenditure was accounted for by variation in body size. The coefficients are not as high as the excellent relationships reported between lean body mass and either basal metabolism (Miller \& Blyth, I953) or maximal oxygen intake (Buskirk \& Taylor, 1957).

The energy expenditure of ergometer cycling has been found to be correlated with body-weight by other investigators (Cotes, I 969 ; Wyndham et al. I966) and in other groups of subjects studied in this laboratory. Nevertheless, in the present group of subjects there was not a significant correlation between the energy expenditure of cycling and body-weight, surface area or lean body mass, but there was a negative correlation with body height: at $\mathrm{I}_{5} \circ \mathrm{W}(P<0.05)$, at $100 \mathrm{~W}(P<0.1)$.

The energy expenditure of each activity $(\mathrm{kcal} / \mathrm{min})$ was correlated with that of another activity but, again, these relationships were not marked $(r<0.59)$, indicating that there was not a pronounced tendency for men to have the same level of encrgy expenditure, relative to the rest of the group, for all activities.

Not all of the activities investigated can be compared directly with other studies in terms of the absolute rates of energy expenditure. However, the mean values for lying and sitting are somewhat greater than the values given by Durnin \& Passmore (1967). The study of Edholm et al. (1955) is probably more nearly comparable to the present one, and these authors quote a higher value for lying but a lower one for sitting. The mean values for cycling are very close to the values predicted from body-weight and work load using an equation described by Cotes (1969).

The regression calculated for the energy expended in walking on firm tracks with loads (routes $I$ and 2, Fig. I and Table 4) in a warm climate is, in relation to speed, similar to that for men performing the same activity on an indoor track in a temperate climate. The steeper slope of the regression for routes $\mathrm{I}$ and 2 was possibly due to the fact that route I was slightly uphill and taken at a fairly high speed whereas route 2 was slightly downhill and taken at a slower speed (Table 2). Oral temperatures recorded after the walks indicated that body temperatures were not very high (mean $37 \cdot 2^{\circ}$, sD 0.4 ) and very few values exceeded $38.0^{\circ}$. The results obtained by Grimby \& Söderholm ( 1962$)$ for men walking on a treadmill were almost identical to the regression on the indoor track results shown in Fig. I, but the equation reported by Ralston 
(1958) for walking on an indoor track gave an underestimate of energy expenditure, particularly at the higher speeds.

The influence of the nature of the terrain on the energy expenditure of walking is clearly seen for routes 3 and 4 (Fig. I). Route 3 was the most arduous, with $67 \%$ of the distance traversing rough ground in between oil palms overgrown with vegetation, and at a walking speed of $100 \mathrm{~m} / \mathrm{min}$ an increased energy expenditure of about $48 \%$ was required compared to that for the firm track of routes $I$ and 2 . Route 4 , having only $17 \%$ of the distance over difficult terrain, required about $16 \%$ increase in energy expenditure over routes $I$ and 2 at $100 \mathrm{~m} / \mathrm{min}$.

A practical application of this study was to be able to predict the energy expenditure of walking over the routes from the weight of the man and his equipment and the speed of walking. It can be seen from Table 4 that the standard errors of estimate range from 9.7 to $12.7 \%$ and it makes little difference whether a multiple regression of energy expenditure, total weight and speed ${ }^{2}$ is used, or a simple regression of energy expenditure (corrceted for total wcight) and speed $^{2}$. It is of interest that energy expenditure of walking over difficult terrain can be estimated with approximately the same efficiency as that of walking on an indoor track.

I wish to thank colleagues and staff of the Physiology Laboratory at West Byfleet for their support in this study.

\section{REFERENCES}

Booyens, J. \& Keatinge, W. R. (1957). 7. Physiol., Lond. 138, 165.

Booyens, J. \& McCance, R. A. (1957). Lancet i, 225.

Buskirk, E. \& Taylor, H. L. (1957). F. appl. Physiol. xx, 72.

Cotes, J. E. (1960). Ergonomics 12, 415.

Durnin, J. V. G. A. (1965). In Human Body Composition: Approaches and Applications p. 73 [J. Brožek, editor]. Oxford: Pergamon.

Durnin, J. V. G. A. \& Brockway, J. M. (1959), Br. J. Nutr. I3, 4I.

Durnin, J. V. G. A. \& Passmore, R. (1967). Energy, Work and Leisure. London: Heinemann.

Durnin, J. V. G. A. \& Rahaman, M. M. (1967). Br. F. Nutr. 21, 681,

Edholm, O. G., Adam, J. M., Healy, M. J. R., Wolff, H. S., Goldsmith, R. \& Best, T. W. (1970). Br. F. Nutr. 24, Iog1.

Edholm, O. G., Fletcher, J. G., Widdowson, E. M. \& McCance, R. A. (1955). Br. F. Nutr. 9, 286.

Grimby, G. \& Söderholm, B. (I962). Scand. F. clin. Lab. Invest. 14, 32 I.

Haisman, M. F. (I 969). The effects of physical exercise upon heart rate and oxygen intake in man, in both hot and temperate environments, with particular reference to body size, body fat and body water content. PhD Thesis, University of Reading.

Kleiber, M. (1947). Physiol. Rev. 27, 511.

Kofranyi, E. \& Michaelis, H. F. (I940). Arbeitsphysiologie Ir, I48.

Miller, A. T. Jr \& Blyth, C. S. (1953). F. appl. Physiol. 5, 3 r.

Ralston, H. J. (1958). Int. Z. angew. Physiol. einschl. Arbeitsphysiol. 17, 277.

Tanner, J. M. (1949). 7. appl. Physiol. 2, I.

von Döbeln, W. (1956). Acta physiol. scand. 37, suppl. т26.

Williams, C. G., Wyndham, C. H., Morrison, J. F. \& Heyns, A. (r966). Int. Z. angew. Physiol. einscht. Arbeitsphysiol, 23, 107.

Wyndham, C. H., Morrison, J. F., Williams, C. G., Strydom, N. B., von Rahden, M. J. E., Holdsworth, L. D., van Graan, C.. H., van Rensburg, A. J., Joffe, A. \& Heyns, A. (1966). Ergonomics 9, I7. 